Colloquia Litteraria

UKSW

$2 / 2015$

ARTUR NOWACZEWSKI

\title{
PRZESŁANIE ROZBITKA. WACTKI ORFICKIE W POEZJI KRZYSZTOFA KARASKA
}

\author{
w każdym pokoleniu \\ pojawiają się ci którzy \\ $\mathrm{z}$ uporem godnym lepszej sprawy \\ pragną wyrwać poezję \\ ze szponów \\ codzienności
}

Zbigniew Herbert, Pan Cogito. Ars longa

Zbigniew Herbert napisał trzy wiersze, w których przywołani są z nazwiska poeci Nowej Fali: Do Ryszarda Krynickiego - list, Widokówka od Adama Zagajewskiego i dedykowany Krzysztofowi Karaskowi wiersz Pan Cogito. Ars longa ${ }^{1}$. Już w samych tytułach widać szczególne poczucie humoru autora Pana Cogito - do Ryszarda Krynickiego wysyła się listy, od Adama Zagajewskiego otrzymuje się widokówki, z Krzysztofem Karaskiem natomiast dyskutuje się o tym, co trwałe w sztuce, i ironicznie komentuje doraźność hierarchii w życiu literackim.

Znana i powtarzana jest opinia Herberta, który pod koniec życia uważał Karaska za najwybitniejszego poetę generacji Nowej Fali: „Jego poezja jest dojrzała, poważna, nośna intelektualnie i świetnie «zrobiona» literacko. Mówiąc językiem sportowym - wyprzedził on o całą długość swoich pokoleniowych przyjaciół”2. Podobnie admiratorem poezji

\footnotetext{
1 Wiersze ukazały się w następujących zbiorach: Do Ryszarda Krynickiego - list, w Raporcie z oblężonego miasta (1982); Widokówka od Adama Zagajewskiego, w Rovigo (1990); Pan Cogito. Ars longa, w Epilogu burzy (1998).

2 Zob. Zbigniew Herbert, Polecam - odradzam, w: tegoż, Węzeł gordyjski oraz inne pisma rozproszone 1948-1998, zebrał, oprac. i notami opatrzył Paweł Kądziela,
} 
Karaska jest Tomasz Burek, który żartobliwie zestawiając dwie plejady poetów - skamandrytów i nowofalowców, przyrównał rangę autora Dziennika rozbitka do Jarosława Iwaszkiewicza ${ }^{3}$. A jednak Karasek w szerszej pozaśrodowiskowej recepcji nie istnieje. Oczywiście jest to los wielu współczesnych autorów, ale trudno znaleźć polskiego poetę, którego dorobek jest tak znaczący artystycznie i intelektualnie przy tak skromnej recepcji akademickiej. Karasek jest właściwie poetą nieopisanym, a jego twórczość to w większej części terra incognita. Można oczywiście dywagować, dlaczego tak się stało, ale zamiast rozwodzić się nad mechanizmami życia literackiego w Polsce po 1989 roku, warto próbować Karaska opowiedzieć dla historii literatury.

Jest to zadanie trudne, ponieważ przyzwyczajono się w drugiej połowie XX wieku do myślenia kilkoma schematami, podług których tworzono hierarchie literackie tego okresu. Jedną z kategorii, której wówczas używano, była pokoleniowość. Sukces generacji, która została przyswojona przez historię literatury, może, paradoksalnie, źle wpływać na recepcję zaliczanych do niej twórców. Ich dorobek ograniczany bywa bowiem do ram zakreślonych w ich młodości, wyznaczonych młodzieńczym-grupowym, programem, a przecież proces dojrzewania twórcy nie kończy się na debiucie i odnalezieniu swojego miejsca wśród rówieśników, ale wchodzi w decydującą fazę właśnie wtedy, gdy autor odnajduje to, co go od generacyjnych kolegów odróżnia, i zdobywa się na własny odrębny głos.

Takiego głosu dopracował się Karasek, który przejawia w ostatnim ćwierćwieczu zadziwiającą aktywność pisarską. Wydał w tym czasie siedemnaście zbiorów wierszy (przed 1989 rokiem - jedynie sześć).

Poeta może być obecny w historii literatury na różne sposoby w kanonie lektur, w recepcji krytycznoliterackiej i akademickiej, posiadając własną legendę biograficzną, wreszcie - w sieci intertekstualnych nawiązań, poprzez które pojawia się w twórczości innych autorów. Ta ostatnia forma obecności jest odzwierciedleniem prawdy, że żadna

Warszawa 2001; pierwodruk: „Tygodnik Solidarność” 1994, nr 51, s. 17. Herbert polecał zbiór wierszy Karaska Czerwone jabłuszko.

3 Zob. Tomasz Burek, Dzieło niczyje, Kraków 2001, s. 30-49. 
twórczość nie powstaje w zupełnej izolacji; poeta albo „zaprasza” innych twórców do własnego poetyckiego świata - poprzez dedykacje, aluzje, nawiązania - albo w podobny sposób sam jest „zapraszany” do twórczości innych poetów i przez to w niej obecny. Toczy się więc na tym poziomie nieustanny dialog z tradycją, ze współczesnymi i z potomnymi. To spełnianie się w dialogu jest bliskie Krzysztofowi Karaskowi, który wielokrotnie dedykował wiersze swoim kolegom po piórze i który równie często był takimi dedykacjami obdarowywany. Poświęcali mu wiersze nie tylko jego mistrzowie, jak Zbigniew Herbert, nie tylko rówieśnicy i pokoleniowi przyjaciele (Julian Kornhauser), ale także uczniowie, fani, przyjaciele z młodszych generacji. Jest Karasek ceniony w znacząco różniących się środowiskach: w kręgach poetów skupionych wokół rzeszowskiej „Nowej Okolicy Poetów”, sopockiego "Toposu” czy Instytutu Mikołowskiego. Autor Godziny jastrzębi przyciągał do siebie młodszych twórców nie tylko siłą swojej poezji, ale i charyzmatyczną, barwną osobowością.

Poezja Karaska jest bardzo erudycyjna. Jej autor korzysta z rozległych kulturowych zasobów - literatura, filozofia, malarstwo, muzyka klasyczna, historiografia, sport - w każdej z tych dziedzin Krzysztof Karasek posiada bardzo rozległą wiedzę. Przy czym żadną z nich nie zajmuje się zawodowo (nie licząc tego, że posiada dyplom Akademii Wychowania Fizycznego i że za młodu trenował skok o tyczce). To humanista formatu spotykanego już dziś niezmiernie rzadko. Jego twórczość na tle innych poetów cechuje duża różnorodność tonacji - od poważnych erudycyjnych poematów, w których snuje się filozoficzne rozważania, po wiersze dowcipne, lekkie tematycznie, poetyckie żarty, bon moty. W czasach, gdy tak bardzo wzrosła rola literatury faktu oraz literatury dokumentu osobistego, szczególnie ważnym elementem jest nie tylko lektura dzieł, ale też doświadczanie literatury przez obcowanie z wybitnymi twórcami. Karasek znał wielu wielkich swojej epoki, z niektórymi się przyjaźnił. Miarą ich wielkości była między innymi błyskotliwość w bezpośrednim kontakcie; obserwował swoich mistrzów i kolegów w różnych sytuacjach i z tych obserwacji wywodził wnioski; miara życia osobistego nie jest ostatecznym kryterium oceny twórcy, ale również nie należy go pomijać. 
Od przeszło dwudziestu lat wiersze Karaska spaja wyrazista figura bohatera. Tę personę lityczną nazwał poeta rozbitkiem. Skutkuje to kreowaniem wizji świata po klęsce, dystansem wobec siebie, brakiem złudzeń, ale też wielką pochwałą życia.

I wreszcie - najważniejsze - dla Krzysztofa Karaska poezja jest głównym narzędziem poznania. On, owszem, filozofuje, posiada nieprzeciętną malarską i muzyczną wrażliwość, jest erudytą, ale wszystko to podporządkowuje poezji. Wiersz jest ostateczną miarą rzeczy, a pisanie czymś niezbędnym dla pełni człowieczeństwa. To akcentowanie bycia poetą wydaje się wręcz natrętne jak na dzisiejsze czasy, właśnie „niedzisiejsze”, jak gest niepodległości w stosunku do mód, trendów, społecznych oczekiwań (czy raczej społecznej obojętności).

Rozbitek funkcjonuje w świecie, w którym marginalizacja poezji jest faktem, ale przyjmuje ten stan rzeczy jako coś naturalnego, jego pisarstwo nie jest lamentem nad upadkiem kultury. U Karaska wyobraźnia żywi się kulturą, ale także - kultura wyobraźnią. Wyobraźnia ma jednak jedną zasadniczą przewagę. Kultury można się nauczyć, można ją nabyć, nawet można nią nasiąknąć - wyobraźnia zaś jest wrodzona, źródło podsuwanych przez nią obrazów nie zawsze jest jasne. Poetą bez kultury być trudno, ale jest to możliwe. Nie można być poetą bez wyobraźni.

Rozbitek jest najważniejszą z figur stworzonych przez Karaska. Jak można go zdefiniować? Najpełniej uczynił to poeta w posłowiu do II części Dziennika rozbitka. Wyjaśnia tam, co różni jego bohatera od podmiotów kreowanych przez poetów-katastrofistów. Rozbitek to nie ktoś przegrany ani nie ktoś, kto jak katastrofiści oczekuje katastrofy, przygotowuje się na jej przyjście:

Rozbitek to ktoś po katastrofie, kto ją przeżył, ocalał i wyszedł z niej wzmocniony. Katastrofie wiary. Katastrofie miłości. Katastrofie obumierania ciała, każdej innej [...] Ktoś, kto żyjąc po katastrofie nie uważa tego faktu za coś niezwykłego. Uważa go za dziedziczoną konieczność, a nawet oczywistość, z którą musi żyć, taką jak grzech pierworodny; musi nauczyć się żyć. Nie fetyszyzując katastrofy - jak katastrofista - rozbitek uważa, że żyje po niej pełniej, że prawdziwy, 
pełny wymiar człowieczeństwa wyłania się dopiero po niej. W tej intuicji jest bliższy raczej Dostojewskiemu, dla którego upadek wpisany jest w kondycję człowieka, w samo jego bytowanie na ziemi, i że opatrzność poddając go - za jego pomocą - próbie, stwarza mu niepowtarzalną szansę, by mógł wziąć sprawy w swoje ręce, by mógł sam wpłynąć na swój los.

Poeta przywołuje ciąg postaci-rozbitków, ludzi po katastrofie: biblijny Adam, mityczny Orfeusz, bohater Moby Dicka - kapitan Ahab, bohater Londona - kapitan Larsen, Klabautermann z Latajacego Holendra, bohater sonetu Burza Mickiewicza, bohater Rymów starego marynarza Coleridge'a, Raskolnikow.

W tej galerii postaci szczególne miejsce zajmuje Orfeusz.

Oczywiście nawiązanie do mitu orfickiego nie jest czymś nowym. Sięgano do niego w wielu epokach. Szczególne znaczenie nadali mu romantycy. Maria Janion w Goraczce romantycznej pisze o dwóch odmianach romantyzmu - orfickiej i tyrtejskiej. Odmiana orficka zakładała zejście w głąb duszy mistycznej, tyrtejska zaś - w głąb dziejów. Ale co ważne - obie podkreślały konieczność poznania siebie w trakcie wędrówki lub pielgrzymki ${ }^{5}$. Postać Orfeusza wiązano z poezją natchnioną. Romantyków interesowały różne aspekty mitu Orfeusza - wyprawa Argonautów, miłość Orfeusza i Eurydyki, inicjacja w misterium, magiczna moc poezji Orfeusza, śmierć z ręki Menad. Orfeusz łączył w swojej osobie kulty dwóch antagonistycznych bogów: Apollina i Dionizosa; „występuje też jako mediator żywych i umarłych, ucieleśnia też romantyczne pragnienie powrotu do pierwotnej jedności, połączenia tego, co rozdzielone, we wszystkich możliwych wymiarach: rzeczywistości materialnej i spirytualnej, ziemskiej i kosmicznej"6. Motywy orfickie pojawiają się w utworach

4 Krzysztof Karasek, Dziennik rozbitka II, Sopot 2004, s. 50.

5 Por. Maria Janion, Czas formy otwartej. Tematy i media romantyczne, Warszawa 1984, s. 14. Odkrycie romantyzmu orfickiego przypada według badaczki na okres Młodej Polski, która sięgnęła do później twórczości Juliusza Słowackiego. Zob. Maria Janion, Gorączka romantyczna, Warszawa 1975, s. 166.

${ }^{6}$ Zob. Magdalena Siwiec, Orfeusz romantyków. Mit o Orfeuszu w twórczości Juliusza Słowackiego i Gérarda de Nerval w kontekście epoki, Kraków 2002, s. 131. 
Kazimierza Wierzyńskiego, Konstantego Ildefonsa Gałczyńskiego, Stanisława Balińskiego, Aleksandra Wata, Adama Ważyka, Romana Branstaettera, Jana Bolesława Ożoga"7.

Przywoływano Orfeusza również w dwudziestowiecznej eseistyce. Józef Wittlin rysował jego postać na tle II wojny światowej, w perspektywie obozów zagłady. Ukazywał bezsilność poezji wobec totalitaryzmu, brak jakiejkolwiek jej mocy sprawczej, marginalizację następującą wskutek cywilizacyjnego postępu. Akcentował też rozbrat poezji z muzyką, który odebrał poezji pierwotną siłę. Powoduje to, że kondycja poety we współczesnym świecie musi być zdefiniowana inaczej niż w przypadku jego mitycznego pierwowzoru:

Mityczny Orfeusz śpiewem swym dzikie bestie ugłaskał, iż przycupnęły u jego stóp [...] Dzisiejszy Orfeusz nie ma już tej mocy. Nie potrafi nawet poskromić dzikiej bestii zamkniętej w klatce ludzkiego serca. [...] Piekło mitycznego Orfeusza znajdowało się pod ziemią. To był Hades, gdzie mieszkali umarli. Piekło dzisiejszych Orfeuszów - ach, nadto dobrze je znamy - to ziemia zamieszkiwana przez żywych ludzi. Nasi Orfeusze, poeci bez lir i muzycy bez władzy, też niekiedy wyrywają nam dusze z tego piekła, w którym żyjemy. Ale ich głos jest za wątły, żeby mógł zagłuszyć zabójczy łoskot doczesności, piekielny ryk morderczych maszyn. Dziś musi przekrzyczeć, nawet w czasie pokoju, straszliwe piekło dźwięków sztucznych, będących dziełem człowieka ${ }^{8}$.

Z kolei Zbigniew Bieńkowski w Piekłach i Orfeuszach pisał o dwóch skrzydłach współczesnej literatury - „jasnym i czarnym”, którego patronami są Lew Tołstoj i Fiodor Dostojewski. „Czarne skrzydło” ma otwierać drogę do piekieł, w tym nurcie Bieńkowski umieścił twórczość Kafki, Joyce’a, Faulknera. Eksplorują oni „podziemie

\footnotetext{
7 Por. Stanisław Stabryła, Hellada i Roma w Polsce Ludowej. Recepcja antyku w literaturze polskiej w latach 1945-1975, Kraków 1983; Stanisław Stabryła, Hellada i Roma. Recepcja antyku w literaturze polskiej w latach 1976-199o, Kraków 1996.

8 Józef Wittlin, Orfeusz w piekle XX wieku, Kraków 20oo, s. 428.
} 
człowieczeństwa", zmagają się sami z sobą, ze swoim wnętrzem9 Koncepcje obu pisarzy - Wittlina i Bieńkowskiego - pozostają więc w dużym stopniu zbieżne. $Z$ mitu orfickiego wybierają oni zejście do piekła, przy czym poszerzają jego znaczenie - nie jest to piekło $\mathrm{w}$ rozumieniu dantejskim, ale także podziemie w znaczeniu, jakie nadał mu Dostojewski, piekło własnego wnętrza.

Dla Karaska Orfeusz jest postacią wyjątkową, bo łączy w sobie cechy rozbitka i poety. Co ważne, reinterpretacja mitu orfickiego przez Karaska związana jest ze zmianą statusu poety we współczesnym świecie (m.in. po „śmierci poezji”, obwieszczonej przez Tadeusza Różewicza). Figurę rozbitka należy zestawić z Różewiczowskim ocalonym. W obu przypadkach bohaterowie muszą odnaleźć się w życiu po katastrofie. Zachodzą jednak między nimi wyraźne różnice. Bohater Różewicza to człowiek młody, który zetknął się z wojną, widział upadek człowieczeństwa, klęskę moralności w zderzeniu z rzeczywistością obozów, klęskę kultury. Doświadcza on sytuacji, w której świat wartości obrócił się w ruinę i w którym nie można rozróżnić dobra i zła. Szuka więc „przewodnika i mistrza”. Katastrofa rozbitka (u Karaska) następuje w innym momencie życia - to doświadczenie człowieka dojrzałego, znajdującego się w mickiewiczowskim „wieku klęski”. On nie poszukuje już mistrza, lecz sam musi się nim stać. Widać tu oddźwięk filozofii egzystencjalizmu, która była bliska Karaskowi w młodości. Wedle jej założeń egzystencja poprzedza esencję - człowiek, aby się zdefiniować, potrzebuje wpierw „zdarzyć się”, nabrać doświadczeń; doświadczenie jest więc niezbędne do tego, aby odnalazł siebie. Ów „ocalony” zatem, choć żyje po katastrofie, wciąż jej doświadcza - katastrofa pozostaje w nim jak otwarta rana, sam rozbitek natomiast już zaakceptował swoją kondycję, nabrał dystansu wobec klęski.

W tomikach Karaska po 1989 roku wątki orfickie pojawiają się wielokrotnie $^{10}$. Działo się to już wcześniej - w tomie Prywatna hi-

9 Zob. Zbigniew Bieńkowski, Piekła i Orfeusze. Szkice z literatury zachodniej, wyd. II, Warszawa 2009, s. 47-49.

10 Zob. Rady dla Orfeusza, w: Dziennik rozbitka, Mikołów 2012; Z objawień orfickich, w: Dziennik rozbitka II, dz.cyt.; Gondwana, w: Gondwana i inne wiersze, 
storia ludzkości (1979) znajdziemy prozę poetycką Orfeusz w barze mlecznym. Poeta zderzył tam motyw mitologiczny z trywialnością współczesnego życia codziennego. Jeszcze w datowanym na rok 1987 wierszu Orfeusz Karasek posługiwał się poetyką zbliżoną do tekstów swojego mistrza Zbigniewa Herberta, pobrzmiewały w nim echa Apolla i Marsjasza: „Poeta stroi instrumenty”, „dźwięczą litery, brzęczy lutnia głowy”, "gasną skrzypce ciała”. W podobny sposób opisywał Herbert rozdzierane cierpieniem ciało Marsjasza. W obu utworach (Herberta i Karaska) pojawia się obrazowanie łączące fizjo$\operatorname{logię~z~muzyką.~W~latach~dziewięćdziesiątych~Karasek~prowadzi~już~}$ równorzędną rozmowę z Herbertem. W Dzienniku rozbitka pojawia się wiersz Rady dla Orfeusza, który można uznać za programowy, tak jak Przesłanie Pana Cogito. Warto go przytoczyć w całości:

\section{Rady dla Orfeusza}

Światło objawia gramatykę cienia, ciemność obnaża logikę poznania, wiara odsyła nas do przeszłości.

Widzimy niejasno, w pomieszaniu, czas załamuje się, a przestrzeń tężeje, to co widzialne rodzi niewidzialne, co niewidzialne otwiera równinę po której kroczą Szekspir i Rimbaud.

Więc nie oglądaj się za siebie, światło jest ciemnym deszczem, który piją zmarli, nie mów, że nie wiedziałeś. Ludzie oniemieli od tej wiedzy, z którą wszyscy, sami musimy żyć. Światło jest kroplą, zlizuje je spod powiek poranny śnieg podczas gdy horyzont, jak linia w ręku malarza się wygina. Twoim jest powietrze,

Warszawa 2006; Tryptyk orficki, w: Gry weneckie, Sopot 2007; Orfickie oraz Orfeus redivivus, w: Wiatrołomy, Sopot 2011; Ukaszenie orfickie a życie w realu, w: Słoneczna balia dzieciństwa, Sopot 2013. Cytaty z tych wierszy według powyższych wydań. 
niepamięć i zdumienie. I jeszcze

chwila, gdy mija. Była,

więc jest. Odżywiaj się nią

lecz nie patrz, nie spoglądaj za siebie, to ona właśnie

cię pożre gdy się w nią wbrew mitom

zapatrzysz. Idź

gdzie syreny wiodą swój miodny śpiew,

miej oczy zwrócone ku świętym ołtarzom, nie drżyj

gdy nieprawości całują cię wargi. Patrz

uważnie, aż do najokrutniejszej wiedzy, niech niesie cię

jak echo nieboskłon, jego blask

mroźnym światłem jutrzenki osmali ci twarz.

Wydźwięk każdego z wierszy - i Przesłania Pana Cogito Herberta, i Rad dla Orfeusza Karaska - jest pod wieloma względami podobny. Ich zestawienie wydaje się uprawnione ze względu na nawiązania w obu do mitu o Orfeuszu. W wierszu Herberta pojawia się przecież „złote runo nicości”, które wprost odsyła do wyprawy Argonautów; Orfeusz odegrał w niej znaczącą rolę.

I Herbert, i Karasek piszą po katastrofie. Można ją rozpatrywać jako katastrofę, która dotknęła europejską kulturę, wiarę, ale także ich bohaterów - w wymiarze osobistym, egzystencjalnym; wreszcie metapoetyckim. O ile jednak Przesłanie Pana Cogito nawiązuje do tradycji tyrtejskiej, dostosowuje ją do realiów codzienności i postuluje uporczywy heroizm inteligenta-spadkobiercy, strażnika starych mitów wbrew wyrokom historii, o tyle Rady dla Orfeusza obejmują inny obszar doświadczenia, oswajany poprzez tradycję orficką. Ważność przesłania Pana Cogito polegała na społecznym znaczeniu jego postawy, obywatela „królestwa bez kresu” i „miasta popiołów”, zagrożonego przez „szpiclów, katów, tchórzy”. Przesłanie rozbitka sformułowane przez Karaska ma przede wszystkim wymiar osobisty, gdyż najważniejsze doświadczenia egzystencjalne i sytuacje graniczne przeżywa się w samotności. Orfeusz Karaska też jest w drodze, ale to droga, która właśnie trwa, jest w tej chwili doświadczana. Bohater Herberta zmagał się z rzeczywistością zewnętrzną, z piekłem historycznym. Bohater Karaska to przede wszystkim ktoś, kto przezwycięża piekło we własnym 
wnętrzu, kto wbrew wszechogarniającej depresji pobudza swoją wolę życia. O ile w wierszu Herberta światło było odległe - dawało znak w górach, o tyle u Karaska doświadczenie światła jest niezbędne do istnienia, do wzrostu. Światło to opisano z malarską wrażliwością, bardzo istotne jest to, by bohater potrafił uchwycić chwilę, stworzyć impresję na jej temat. U Herberta przeszłość jest statyczna, to stały punkt odniesienia, takie gruzowisko mitów, z którego wygrzebuje się „zaklęcia ludzkości, bajki i legendy”. U Karaska przeszłość jest dynamiczna jak teraźniejszość, jest realna, bo to ona daje siłę do życia: „wiara odsyła nas do przeszłości”. Kapitał osobistych doświadczeń, wszystkich doświadczeń: i tych dobrych, i tych złych, jest bogactwem. Bo pełnię życia tworzy dialektyka światła i cienia. Przeszłość stanowi też glebę wyobraźni, związek z przeszłością jest organiczny, wręcz sensualny. Wedle mitów śpiew Orfeusza oddziaływał nie tylko na ludzi, ale też na rośliny, oswajał zwierzęta, mógł zatrzymać wzburzone fale. Obudzenie w sobie poezji, funkcjonowanie jako jej medium ma wymiar terapeutyczny. Przesłanie Pana Cogito i Rady dla Orfeusza to wiersze wobec siebie komplementarne. Ale pobudzeniem do działania jest dla rozbitka także teraźniejszość, możność dziwienia się i - inaczej niż u Herberta - umiejętność zapominania, uwalniania się od przytłaczających doświadczeń. U Herberta pamięć i wzbudzanie w sobie emocji z przeszłości były wartościami najwyższymi. Karasek jest przekonany, że aby żyć, nie można się oglądać wstecz, bo przeszłość jest zapisana w nas w sposób naturalny. To właśnie spojrzenie wstecz, lęk zgubiły Orfeusza, gdy wyprowadzał z Hadesu Eurydykę. Ten lęk w poezji Karaska oczywiście istnieje, ale jest nieustannie zaklinany, oswajany. Wszystko po to, żeby przyjąć życie po stoicku, takim, jakim jest. Ale stoicyzm Karaska nie jest wygaszeniem emocji, obojętnością, jest równowagą uczuć nawzajem się znoszących. Dlatego „mroźne światło jutrzenki osmala twarz".

W jesieni życia Krzysztof Karasek identyfikuje się z Orfeuszem. Tak pisze w wierszu $Z$ objawień orfickich:

Nie wiedząc o tym zstąpiłem do podziemi.

Było jak nadziemie, 
tylko światło było inne. Zstępujące.

[...]

Nie przypuszczałem, że to tak szybko się stanie,

myślałem.

Ledwie pogrzebałem swoich mistrzów

a sam stałem się mistrzem.

[...]

Cienie niepocieszonego dziedzictwa

Światła przesuwały się obok mnie, jakby otulone grubą warstwą mgły.

Bardzo wielu ludzi, których poeta znał, zmarło. Stał się więc, szybciej niż spodziewał, pośrednikiem między światem żywych i zmarłych, depozytariuszem wiedzy, którą od poprzedników otrzymał. Teraz to młodsi rozmawiają z nim tak, jak on rozmawiał ze swoimi mistrzami. Poeta nosi w sobie "cień niepocieszonego dziedzictwa światła”, żyje, ale jego życie jest w dużej części już po drugiej stronie, znajduje się w podziemiu.

W jednym ze swoich wierszy Karasek używa określenia „ukąszenie orfickie”, co jest oczywistym nawiązaniem do „ukąszenia heglowskiego”. „Ukąszenie orfickie” chroni jego bohatera przed Heglem, choć młody Karasek, tak jak i jego rówieśnicy z Nowej Fali, pisał wiersze poddające się współczesności, „duchowi czasu”, zaangażowane. Dość szybko jednak poszedł swoją, niezrozumiałą dla generacyjnych kolegów drogą. Interesujący jest $\mathrm{z}$ tego punktu widzenia jego poetycki dialog z Julianem Kornhauserem. Po lekturze tomiku Gondwana Kornhauser napisał w 2007 roku przejmujący wiersz Do Krzysztofa Karaska ${ }^{11}$. Jest on portretem autora Dziennika rozbitka, Kornhauser kreśli w nim wizję ukąszonego poezją młodzieńca:

Kiedy zapadasz w sen razem z kwidzyńskim niebem spod kożucha, zapala mi się światło naszej młodości, której nikt nie chciał strzec.

Twoje w tamtym czasie gniewne rimbaudowskie wizje i skargi spadały na mnie i przyjaciół jak lawina górskiej wyprawy donikąd.

11 Julian Kornhauser, Do Krzysztofa Karaska, „Nowa Okolica Poetów” 2007, nr 2. 
Kornhauser wyznaje, że rozmijali się z Karaskiem. Najkrócej streścić można ich poetyckie wybory, sięgając po typologię stworzoną przez Tadeusza Różewicza w Opowiadaniu dydaktycznym - podział na poetów śmietników i poetów chmur. Pierwszy był poetą śmietników, chciał bowiem zbliżyć się do przedmiotu, elementarnego konkretu, uciekając przed wizyjnością; drugi porzucał trywialność codziennego życia i żył słowami poetów, był poetą chmur, chciał ponad obłokami odnaleźć wizję „całości” świata, mapę mitycznego kontynentu, który jest całością ${ }^{12}$. Kornhauser jako dojrzały twórca rozumie marzenia przyjaciela i po latach oddaje honor jego niepogodzeniu się z utratą „całości” i pościgowi za nią. Być może właśnie wizja wielkiego kontynentu ponad niebem rozbudziła wyobraźnię Kornhausera, który jako poeta jest skierowany ku ziemi, jej szczegółom, drobiazgom, fragmentom mikrokosmosu. Gondwana łączyła kilkaset milionów lat temu Amerykę Południową, Afrykę, Antarktydę, Indie, Australię. Unieważniała więc dzisiejsze rozlane między tymi lądami oceany; ale też łączyła w sobie to, co najgorętsze, najpełniejsze, z tym, co najchłodniejsze, w Gondwanie współistnieją harmonijnie późniejsze przeciwieństwa. To raj rozbitka.

$\mathrm{Na}$ wiersz Kornhausera Karasek odpowiedział dedykowanym przyjacielowi tekstem Orfeus redivivus (Julianowi Kornhauserowi z orfickim pozdrowieniem). Pisze w nim, że nie ma recepty na szczęśliwe życie, nie ma też jedynego właściwego sposobu, aby je przeżyć. Nie mamy kontroli nad swoim losem, on nam się zdarza:

Kto płacze we mnie? Kto się we mnie śmieje?

Życie jest jak wróbel w garści,

\footnotetext{
12 Nieco inaczej ujmuje tę opozycję Grzegorz Kociuba. Według niego Karasek to poeta furiosus, a Kornhauser-poeta kontemplator. W tym ujęciu Karasek jawi się jako poeta gwałtowny, namiętny, ale też natchniony, wierzący, że jest zależny od siły, która go przerasta. Reprezentuje poznawczy maksymalizm, nieufność do tradycji. Natomiast poeta kontemplator marzy o jedności między słowem a rzeczą, wyrazem a jego desygnatem, językiem a światem. Zob. Grzegorz Kociuba, Ciemna kantyczka i blask szarości, w: Było nie minęło. Antologia tekstów krytycznych poświęconych twórczości Juliana Kornhausera, pod red. Adriana Glenia, Opole 2011, s. 23-28.
} 
trzymasz za mocno, udusisz, trzymasz za słabo, odleci.

Życie to zwykły

gorący sen.

Wedle interpretującego ten wiersz Grzegorza Kociuby Orfeusz występuje tu jako jeden $\mathrm{z}$ archetypów twórcy i jego obecność odsyła do typu poety natchnionego, namiętnego, który zgłębia wielowymiarowość ludzkiego losu, objawiającą się w jego życiu i dziele ${ }^{13}$.

Ważnym punktem odniesienia pozostaje dla Karaska poezja Dylana Thomasa. W wierszach orfickich Karasek jest bowiem piewcą witalnej siły ukierunkowanej pionowo. Wielokrotnie nawiązywał do słynnego wiersza Thomasa rozpoczynającego się frazą: „Ta siła, która przez zielony lont prze kwiaty”. Także metafory łączące w sobie skrajności, takie jak obecna w tym wierszu „febra mrozu”, często występują w utworach Karaska. Jego z pozoru papierowa, intelektualna poezja jest przesycona energią życiową. Zwroty wyobraźni, surrealistyczna śmiałość obrazów, efektowne jukstapozycje - wszystko to jest wyrazem rozsadzającej autora tych wierszy witalności. Poetycka wizja bierze się z nadmiaru, siła słowa zależy od tego, kto je wypowiada. Często czytelnicy nie potrafią wczuć się w wiersze Karaska, gdyż napisane są one w poprzek poprawności dominujących poetyk epoki. Tę poprawność wyznacza z jednej strony kolokwialny, unikający barokowości biały wiersz Różewicza, z drugiej - późna poezja Czesława Miłosza i - za jej pośrednictwem - obecność retoryki. Młodsi o dwie generacje od Karaska poeci ulegają zasadniczo wpływom dwóch poetyckich dykcji - Andrzeja Sosnowskiego i Romana Honeta. Tymczasem Karasek jest silnie zakorzeniony w tradycji polskiej awangardy. Pozostaje też wierny swoim młodzieńczym fascynacjom poetyckim, czym należy tłumaczyć jego dystans wobec poezji pokoleniowych kolegów - Adama Zagajewskiego i Ryszarda Krynickiego. Bliżej Karaskowi do linii Przybosia niż do linii Miłosza, ale ważniejsi poeci to dla niego Adam Ważyk i Zbigniew Herbert. Trzecim mistrzem jest zupełnie jako poeta współcześnie niedoceniany Zbigniew Bieńkowski

13 Tamże, s. 27. 
ze swoimi skłonnościami do snucia długich filozoficznych poematów. Ten patronat zaciemnia odbiór twórczości Karaska, gdyż typ poetyki reprezentowany przez Bieńkowskiego zdaje się być współcześnie ślepą uliczką. Jak łączy Karasek w swojej poetyce tak odległe inspiracje? Jest to możliwe dzięki stworzonej przez niego na własne potrzeby formule poezji, którą najzwięźlej przedstawił chyba w posłowiu do tomiku Gondwana i inne wiersze:

Poezja jest ścieśnianiem, mową bardziej zgniecioną, sprasowaną [...] To mowa, z której wycięto „nudne” słowa, słowa pozbawione znaczeń - lejącą się wodę narracji. Żyjemy w rozrzedzonym powietrzu języka. $Z$ jednej strony nieplewiony obszar mowy, z drugiej poezja $[\ldots]^{14}$.

Poeta może więc ulegać albo językowi potocznemu, co grozi „roztopieniem się w gadaniu"15 albo dążyć do sublimacji, co jednak może sprawić, że znaczenia przestaną być czytelne i język stanie się wieloznaczny. „Mowa poniża język, poezja go wywyższa. Sztuką czynią kontrasty" - pisze Karasek ${ }^{16}$. To poeta ryzykant, który często zbliża się do obu biegunów - i do "gadania”, i do skupienia na słowie. Dlatego być może jest do dziś twórcą słabo odczytanym.

\section{Summary \\ The Message of a Castaway. Orphic threads in Krzysztof Karasek's Poetry}

Although Krzystof Karasek counts among the most outstanding representatives of the Nowa Fala (New Wave) generation, his poems have not been subject to detailed analysis so far. The author attempts to highlight the meaning of the Orphic threads in Krzysztof Karasek's poetry written after 1989. For more than twenty years Karasek's poems have been tied to each other by a suggestive figure of a hero named by the poet a 'castaway'. This castaway's characteristics include distance to himself and lack of delusion

\footnotetext{
14 Krzysztof Karasek, Gondwana i inne wiersze, dz.cyt., s. 69-70.

15 Tamże.

16 Tamże.
} 
about the condition of the world after personal and cultural collapse. Still, it also includes great appraisal of life. The poet, defining the figure of the castaway, calls in a number of castaway figures, characters after catastrophe, among which one can find the mythical Orpheus. The article addresses the originality of Karasek's idea with regard to his polemical texts which engaged with Zbigniew Herbert's and Julian Kornhauser's works.

Artur Nowaczewski (Uniwersytet Gdański) - adiunkt w Katedrze Teorii Literatury oraz Krytyki Artystycznej UG; autor trzech książek literaturoznawczych: Trzy miasta, trzy pokolenia (2006); Szlifibruki iflâneurzy. Figura ulicy w literaturze polskiej po 1918 roku (2011) oraz Konfesja i tradycja. Szkice o poezji polskiej po 1989 roku (2013). 